\title{
Composition of the Characidae Family (Order: Characiformes, Pisces) in an Andean-Amazonian River, Case Study Hacha River Basin (Caquetá-Colombia)
}

Remic io-Duque, J .H. ${ }^{1}$, Pela ez-Rodriguez, M. ${ }^{1}$, Gaspar, S. ${ }^{2}$

'Research Group on Quality and Preservation of Aquatic Ecosystems, Facultad de Ciencias Basicas, Universidad de la Amazonia, Florencia (Caquetá) Colombia.

2Ekolur Environmental Consultancy, SLL, 20180 O ia rtzun (G ip uzkoa). Spa in.

Corresponding author: jremicio@uniamazonia.edu.co, mpelaez@unia mazonia.edu.co

\section{Abstract}

An ic hthyologic al inventory of the Characidae family (order: Cha ra ciformes) was ca ried out on a n altitudinal gradient (2112 to 248 m.s.) of an Andean-Amazonian river basin of the Hacha river, located in the municipality of Florencia, department of Caquetá (Colombia). The collections were developed in 10 sampling stations through two fishing gears (electric fishing and traditional fishing); between the months of October to March, in two consecutive years (2009 and 2010), corresponding to the low water period. 459 individuals were collected, identified and grouped into 14 genera and 18 species; the highest abundances corresponded to the species Hemibryc on sp. (151 ind ividuals), Boehlkea cf. fredcochui (88), Creagrutusamoenus (50) and Creagrutusc ochui (35). In conclusion, it can be indic ated that the greatest wealth (12sp.) occurs in the lower basin of the river, it is also noteworthy that the 18 species a re new reports for the Hacha river basin, 12 species for Caquetá and one (1) species for the Colombian Amazon.

Keywords: Characidae, Hacha River, Andean-Amazonian. 


\section{Introduction}

The order Cha raciformes is composed of approximately 1962 species, which correspond to about 34\% of freshwater species in the world (ALBERT et al., 2011), grouped into 274 genera and 18 families (GÉRY, 1977, REIS, KULLANDER 2003, MOYLE, CECH, 2004, NELSON, 2006). By regions, the Amazon basin exhibits the highest ric hness with about 1450 species of fish (GÉRY, 1984), of this number a lmost 50\% a re spec ies of the order Chara c iformes (Nelson, 2006). However, despite the high wealth, there are regions of the basin where the knowledge of this order is meager, such as the Colombian Amazonian Andean region and in particular the case of the river basin of the Hacha River, located in the municipality of Florencia (Caquetá), which supplies drinking water to the municipality (the most populated city of the Colombian Amazon), the Hacha River is the main place of recreation and, a little noble use, as a receiver of the wastewater of the city (PELÁEZ et al., 2006).

The first samplings for the Department of Caquetá were carried out by Brother Nicéforo María on the Ortegüaza Rivera round 1900, the results of which were published by Fowler (1943, 1945). Mojica et al. (2005) and Galviset al. (2007) reported 30 species for the order Characiformescollected in tributa ries of the Caquetá river, a mong them the Ortegüaza river. At the local level, the Universidad of the Amazonia, has c a rried out some works, results of degree projectsand master thesis such as Celis, Ortiz (2003); Rueda, Alma rio (2004); Díaz, Esc obar (2004); Celis (2010); C há ves (2011) and Perdomo et al. (2012). The following is an updated list of the Characidae family (order: Characiformes) of the Hacha River Basin, integrated from the literature review, the biological collection of the Institute of Natural Sciences (ICN) and what was reported in this work.

\section{Materials and methods}

The study wascarried out in the ma in channel of a mounta in river (Hacha) of the Andean-Amazonian region, department of Caquetá (Colombia) between the coordinates $01^{\circ} 52^{\prime} 40,7$ “ N- 75 ${ }^{\circ} 40^{\prime} 44,1$ “W and 133'19,2" N-7531'55 “W. The hydrographic basin covers an area of 490.18 square kilometers and covers a distance of $66.7 \mathrm{~km}$ from its source at 2,400 m. a.s. I. in Cerro Gabinete until its convergence with the Ortegüaza River, at a $n$ altitude of 248 m. a. s. I. (POMCA, 2005) (Figure 1).

The collections were made during two consecutive years, between the months of October to March (low waters) of 2009 and 2010 respectively. These were carried out in 10 sampling stations representa tive of the uses given to the river Hacha (Annex $A$, the list of struc tural cha ra c teristic s of the stations is presented), through two fishing techniques: tra ditional fishing (cast nets and hooks) and electric fishing (LOBÓN-CERVIÁ, 1991; ELOSEGI, SABATER 2009) in order to capture the largest number of specimens present in this ecosystem. The captured specimens were fixed in $10 \%$ formaldehyde, then in 70\% a lc ohol (MOJ IC A et al., 2005; MALDONADO-OCAMPO et al., 2006) and were deposited in the IC N's Ichthyological collection. 


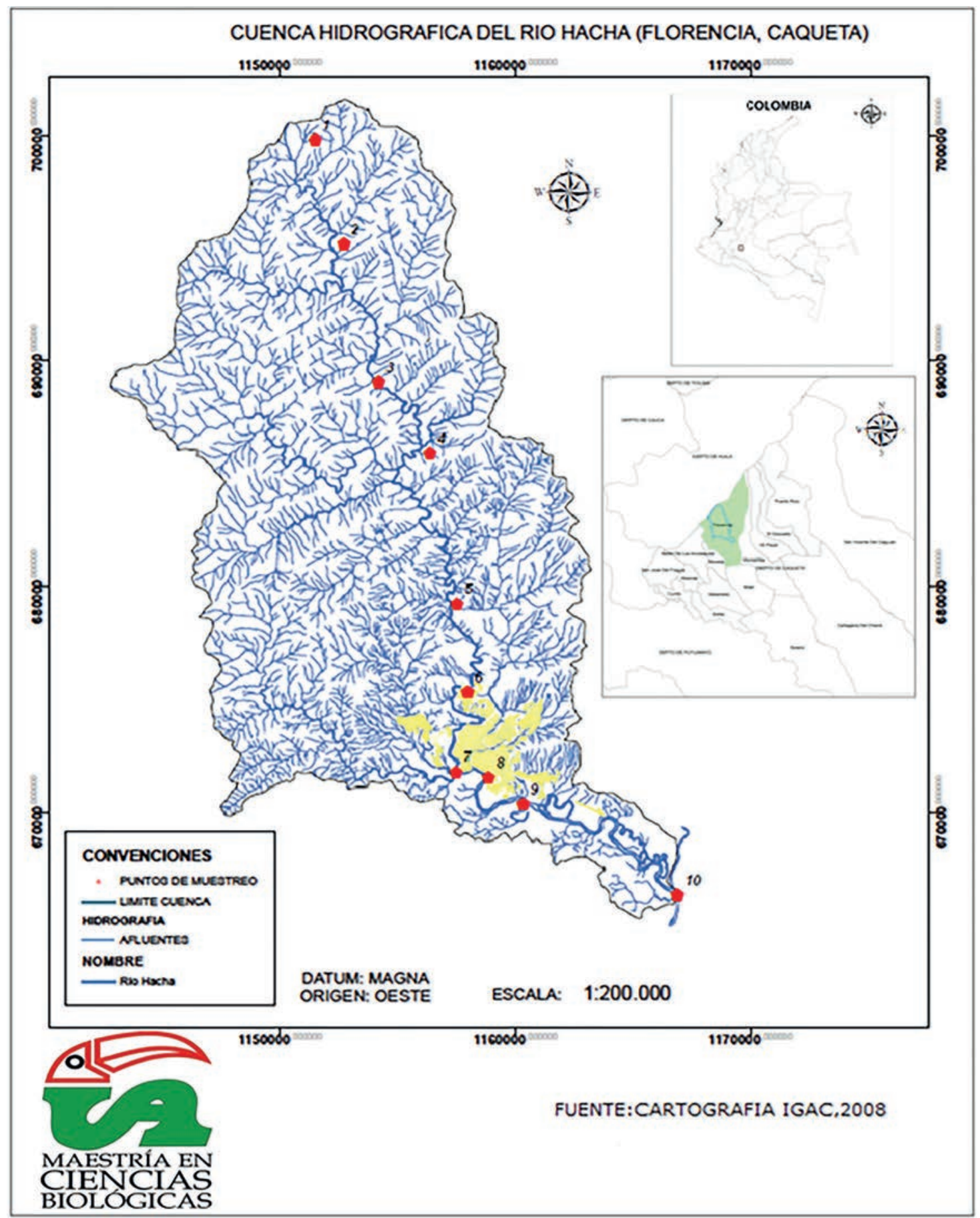

Figure 1 - Geographical location of the study area, municipality Florencia, Caquetá (Colombia).

For the taxonomic determination, we followed Fowler (1943); Fowler (1945); G ÉRY (1977); C a stro (1997); Mojic a (1999); Maldona do et al. (2006); G regory-Mald ona do (2006); Ortega Lara et al. (2006); Galvis et al. (2007);
Rubio (2007) and Román-Valencia et al. (2013). Likewise, ic hthyologic a I materia I deposited in the reference collection of the ICN-MHN of the Universidad Nacional de Colombia and the advice of specia lists wa s c o nsulted. 


\section{Results}

The results obtained are presented through a systematic list of the ic hthyofauna found in the basin of the Hacha river. We collected 459 individuals grouped into 14 genera and 18 species (Appendix B) and Figure 2.
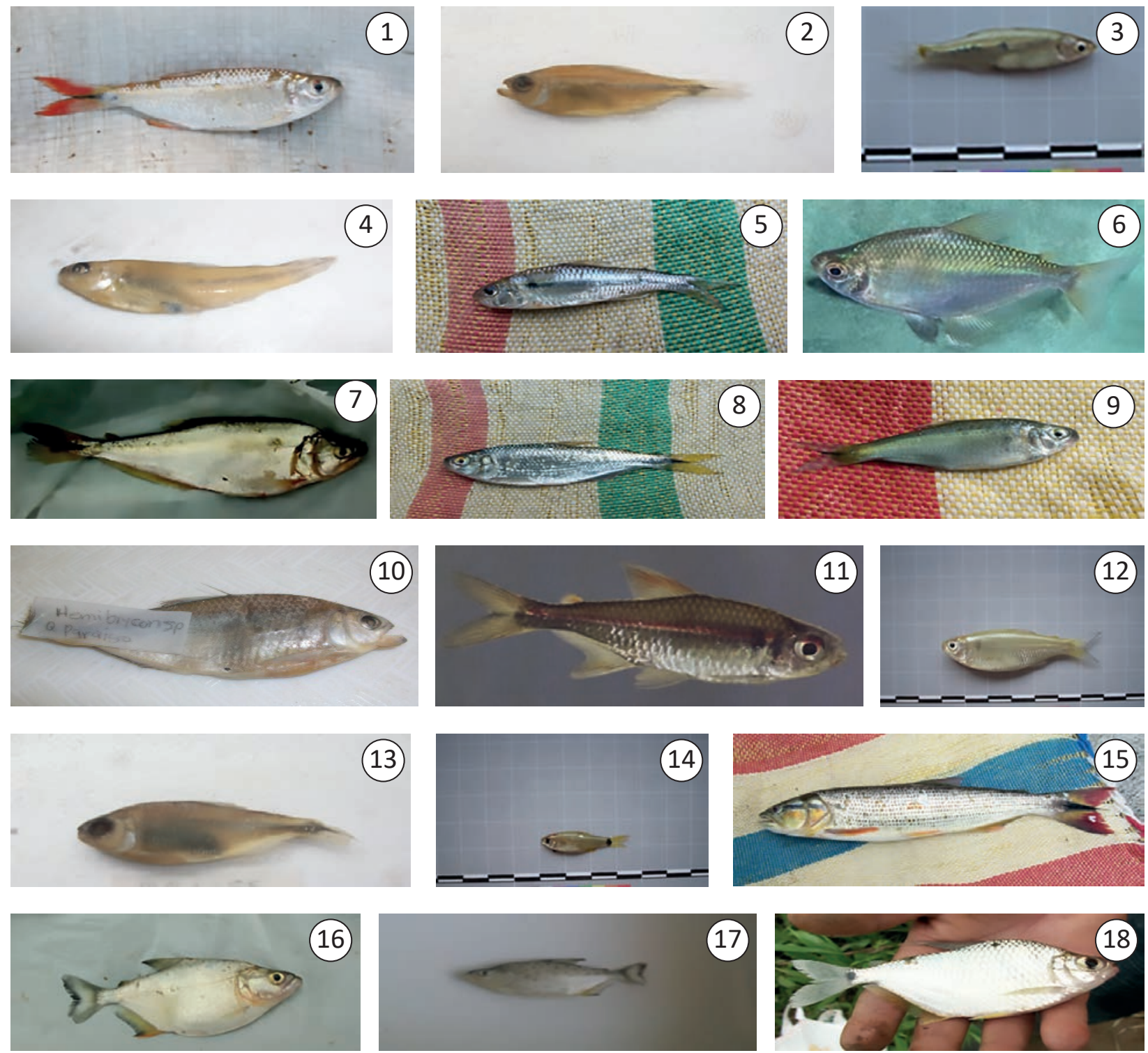

Figure 2 - Species Characidae family 1. Astyanax fasciatus, 2. Astyanax symmetricus, 3. Boehlkea cf. fredcochui. , 4. Creagrutus cf. amoenus, 5. Creagrutuscochui, 6. Ctenobrycon cf. hauxwellianus, 7. Cynopotamusamazonum, 8. Hemybriconsp, 9. Hemibrycon sp2, 10. Hemibrycon sp3, 11. Hyphessobryconsp, 12. Knoduscarlosi, 13. Moenkhausiarobertsi, 14. Odontostilbe cf. caquetae, 15. Salminusaffinis, 16. Pristobryconcalmoni, 17. Serrasalmusrombeus, 18. Tetragonopterus argenteus. 
This list of spec ies inc lud es information on:

- Scientific name: Gender and specific epithet, followed by the a uthor of the description and the year of public ation.

- Species in collection: The number of the file of the deposited species is listed in the Institute of Natural Sciences (INS), Museum of Natural History (MNH), ic hthyology a rea.

- Synonymies: Includes the scientific name, author and year.

- Common name: Reference the regional name of the species.

- Description: Information regarding the pigmentation, morphology, size and morphometry of the species.

- Distribution: It reviews the localities where there are reliable records of the species; they begin with the type loc a lity (altitudinal range in the Hacha river); then, general data of the distribution for Colombia and the Neotropic are referenced, based on the literature review. Also, image of the species is attached.

\section{ORDER CHARACIFORMES: CHARACIDAE FAMILY}

\section{Astyanax fasciatus (CUVIER, 1819).}

Collection number ICN-MHN: 17918.

Synonyms: A. fa sc ia tusortegua sa e (FOWLER, 1943).

Common name: red tail sardine, yellow ta il sardine, tolomba, greedy, old lady (Ven).

Description: Medium-sized fish that reach $17 \mathrm{~cm}$ instandard length (SL), a re silvery color dorsally, cauda I with a well-marked black caudal spot. Some specimens show an intense reddish color in the caudal fin (GALVIS et al., 2007); middle rays of the dark caudal and the other orange with the hya line ends (VARGAS-TISNES, 1989).

Distribution: Located in the stations of the urban area of the city of Florencia between 262-261m. a. s. I.; Fowler (1943, 1945) reported it for the Bodoquero river of Morelia Caquetá; However, in other regions it has a wide distribution as in the Magdalena, Cauca and the Amazon ba sins (FOWLER, 1943; MOJ IC A, 1999; ORTEG A-LARA et al., 2002; G REG ORYMALDONADO, 2006; G a lvis et al., 2007; MALDONADO-OCAMPO et al., 2008; MALABARMA et al., 2003) report ed it from Mexic o to Argentina.

\section{Astyanax symmetric us (EIG ENMANN,} 1908).

\section{Collection number ICN-MHN: 17861.}

Common name: Sardine.

Desc ription: Sma ll fish with SL from 3 to 6 cm, more or less uniform body, terminal mouth. In alcohol it turns brown with a light colored stripe on the ventral side.

Distribution: 262-261 m.a.s.l.; It was loc ated in the stations known as La Floresta and Puente López in the municipality of Florencia (capture method: Electric fishing). Malabarma et al. (2003) reported for the Amazon River basin.

3. Boehlkea cf. fredc oc hui (GÉRY, 1966). Synonymies: Mic robryc onc oc hui (NON LADIG ES, 1950) www.fishba se.org. 
Common name: Little sardine, blue tetra (Per).

Description: Sma ll size fish of 4 to $5 \mathrm{~cm}$ of SL, similar to the Hemibryc on (GÉRY, 1977), irregular lateral line. Its body is met al.lic light blue.

Distribution: 635-262 m.a.s.l.; it was loc ated between the station known as Carañoto the la Floresta station in the city of Florencia (method of capture: electric fishing). Gregory-Maldonado (2006) reported it for the Colombian Amazon.

4. Creagnutusamoenus (FOWLER, 1943). Synonymies: Crea grutusb o ehlkei (GÉRY, 1977).

Common name: Little sa rdine.

Description: Fishes with $\mathrm{SL}$ of $8 \mathrm{~cm}$ are recognized by presenting the maxilla more pronounced than the jaw. They have a gray spot on the dorsal fin and dark patches on the lateral line. The general coloration of the body is silver with reddish overtones and in alcohol presents a clear brown coloration.

Distribution: 635-296 m.a.s.l.; it was collected between the sites known as Paraíso-Carañoto the first bridge (north) of the city of Florencia (capture method: Electric fishing). Fowler (1943) and Galvis et al. (2007) reported it to the Ortegüaza River; Gregory-Maldonado (2006) for the Amazon River basin.

5. Creagrutusc oc hui (GÉRY, 1964).

Collection number ICN-MHN: 17871, 17874, 17887.

821
Common name: Squeaky (Flo rencia), little mojarra, little sardine.

Description: Sma ll spec ies that grows up to $7.9 \mathrm{~cm}$ of SL. With an elongated and cylindric al body, brown with a well-defined horizontal humeral spot and all its fins a re hya line except for the dorsal fin.

Distribution: 890-248 m.a.s.l.; between the sites known as the vereda Sucre to the confluence of the Hacha river with the Orteguaza (methods of capture: traditional fishing and electric fishing). MaldonadoOcampo et al. (2008); Ga lvis et al. (2007); Gregory-Maldonado (2006), reported it in streams of intermediate waters near Leticia.

6. Ctenobryconhauxwellianus (COPE, 1870).

Synonymies: C. spilurusha uxwellia nus, Tetrag ono pterusha uxwellia nus (COPE, 1870).

Common name: Wide sardine (Florence), s. fat, pinky, little mojarra, la mbari (Bra).

Description: Small species that reached $6.5 \mathrm{~cm}$ of SL. Wide body and small sc ales, light brown in the dorsal and silver on the ventral side, with a gray band on the la teral line.

Distribution: 253 - 248 m.a.s.l.; it was located between the Florencia Airport station to the confluence with the Ortegüaza river (capture method: Electric fishing). Galvis et al. (2007); Fowler $(1943,1945)$ reported it for tributa ries of the Caquetá River in the munic ipality of Morelia. It is a lso distributed in the Amazon River basin (MOJ ICA et al. 2005; GREG ORY-MALDONADO 2006; MALDONADO-OCAMPO et al. 2008; WWW. SINCHI.org.Co/2011). 
7. Cynopotamusamazonum (G ÜNTHER, 1868).

Collection number ICN-MHN: 17901.

Subfamily: Cha ra cinae.

Synonymies: Ana c rytuslima esqua mis (COPE, 1878).

Common name: Chango (Caquetá), clear, dog, dentex (Per), cacunda (Bra)

Description: Large species that reached 23 cm of SL of elongated body with a small hump between the dorsal fin and the head, the scales are rough. Its coloration is silver; the caudal and a dipose fins have a yellow hue. Very similar to the Charax species (GÉRY, 1977).

Distribution: 248 m.a.s.l.; it wa s only captured at the confluence (Venecia sector) with the Ortegüaza river (method of capture: Tra ditional fishing). It is loc ated in the Amazon River basin (GREG ORY-MALDONADO 2006; MALDONADO-OCAMPO et al., 2008; WWW.SINCHI.org.co/2011).

\section{Hemibryc on sp. (G ÜNTHER, 1864).}

Collection number IC N-MHN: 17857, 17858, 17918.

Common name: Yellow tail sardine, tolomba, mojara (Per).

Description: Medium-sized fish that reach $17 \mathrm{~cm}$ in SL, a re dorsally dark and la terally silvery in color; the rays of the a nal fin a re orange oryellow (ORTEGA-LARA et al., 2002).

Distribution: 1100-248 m.a.s.l.; It has a wide distribution in the Hacha river basin (method of capture: tra ditional fishing gear and electric fishing). In Colombia, it is also found in the basin of the Meta,
Magdalena and Amazonas rivers (G REG ORY-MALDONADO et al. 2006, GALVIS et al. 2007).

\section{Hemibrycon sp2. (GÜNTHER, 1864).}

\section{Collection number ICN-MHN: 17855.}

Common name: Thunder sardine (Ca quetá), boquilla (Ecu).

Description: Small species that reached $3.5 \mathrm{~cm}$ of SL of color silver and brown on the caudal region.

Distribution: 635-248 m.a.s.l; it was loc a ted between the Vereda Paraíso until the confluence with the Ortegüaza river (method of capture: Traditional fishing and electric fishing ). It is distributed in the Amazon River basin (G REG ORY-MALDONADO, 2006).

10. Hemibryc on sp3. (GÜNTHER, 1864).

Common name: Sardine, tolomba.

Description: Medium spec ies that rea ched $7 \mathrm{~cm}$ of SL of silver color and prominent lower jaw.

Distribution: 262 m.a.s.l.;it was captured in the area called the forest (capture method: electric fishing). It is loc ated in the Amazon basin, O rinoco and Magdalena (GÉRY, 1977; REIS, KULLANDER, 2003; G REG ORY-MALDONADO, 2006; MALDONADO-OCAMPO et al., 2008).

Observation: First report for the Hacha and Caquetá basin.

11. Hyphessobryc on sp. (FO WLER, 1941). Common name: Tetras, little sardines, Colombian tetra. 
Description: Sma ll species that rea ched $5 \mathrm{~cm}$ of SL. They are characterized by having the internal row of premaxillary teeth with five or more teeth on each side, inc omplete lateral line, a dipose fin and caudal non-scaly.

Distribution: 253-248 m.a.s.l.; It wa s collec ted in the a irport sector until the confluence with the Ortegüaza River (capture method: Elec tric fishing). Maldona do et al. (2008), Gregory-Maldonado (2006) reported it for the Colombian Amazon.

12. Knoduscarlosi (ROMÁN-VALENCIA et al., 2013).

Common name: Little sa rdine.

Description: Sma ll species that reached $6.5 \mathrm{~cm}$ of SL. Compressed body, robust and slender. Full la tera I line, silver color and in the yellow outline, in alcohol it is observed of light brown color.

Distribution: 262-248 m.a.s.l.; It was collec ted in the Floresta sector until the confluence with the Ortegüaza River (capture method: Electric fishing). Román-Valencia et al., (2013) reported it for the Amazon River basin.

13. Moenkha usiarobertsi (G ÉRY, 1964).

Common name: Sa rdine, tetra.

Description: Sma ll species that reached the $7.6 \mathrm{~cm}$ of SL of silver color and with a broad humeral sp ot, its fins a re hya line. In alcohol it is observed in brown and some parts in black.

Distribution: 635-296 m.a.s.l.; It wa s loc ated in the middle basin of the Hacha river (capture method: Electric fishing). Fowler (1943), reported for the Ortegüaza River the species Moenkhausialepidura and Moenkha usia ortegua sa e. Also, it is loc a ted in the Amazon River basin (MOJICA et al., 2005; G REG ORY-MALDO NADO, 2006; MALDONADO-OCAMPO et al., 2008; WWW.SINC HI.org.Co/2011).

14. Odontostilbe cf. caquetae (FO WLER, 1943).

Synonymies: Fug itive Cheirod on, Fugitive Odontostilbe, O madeirae.

Common name: Little sardine, moja rra.

Desc ription: Small fish that rea $\mathrm{ch} 4 \mathrm{~cm}$ of SL. Body elongated and brown, with a silver strip that ends in a dark spot that may or may not cover the caudal peduncle (GÉRY, 1977).

Distribution: 261-248 m.a.s.l.; spec ies c aptured in the area called the López bridge to the confluence with the Ortegüaza river (method of capture: traditional fishing and electric fishing). Galviset al. (2007) and Fowler $(1943,1945)$ reported it in the same region. Gregory-Maldonado (2006) reported it for the Amazon River basin.

15. Sa Iminusaffinis (STEINDAC HNER, 1880). Collection number ICN-MHN: 17910.

Subfamily: Sa Iminina e.

Common name: Golden, beaked, blonde, lady (Ecu), male shad (Per).

Description: Medium sized fish that reached $32 \mathrm{~cm}$ of SL. Elongated body shape; caudal without elongation, the caudal lobes a re pink-intense red towards the tips, at the 
base of the yellow fin and a black stripe towards the peduncle, red anal fin, the operculum is a lso pinkish-reddish, the fins present the color yellow, the dorsal part of the body is silver gray and the ventral part white-yellowish (MOJ ICA et al., 2012).

Distribution: 890-253 m.a.s.l.; It was loc a ted from the vereda Sucre to the a irport sec tor of the munic ipa lity of Florencia (method of capture: Tra ditional fishing). It was reported for the Magdalena and Ama zonas river basins (MOJ ICA et al. 2005; G REG ORY-MALDONADO et al. 2006; MALDONADO-OCAMPO et al. 2008; WWW. SINCHI.org.Co/2011).

Observation: In The Red Book of Freshwater Fishes of Colombia, it is classified as vulnerable in the IUC N category ( $A 2 \mathrm{C}$, d) - National in Danger (B1bii, B1ciii) Regional (MOJ ICA et al., 2012). It is a Iso the first report for the basin of the Hacha and Caquetá river.

16. Pristobryc onc almoni (STEINDAC HNER, 1908).

Collection number IC N-MHN: 17912.

Subfamily: Serra sa Imina e.

Synonymies: Se rra sa Imusc a Imoni, S. bilineatus, Pygocentrusb ilineatus.

Common name: Piranha, white piranha (Bra), Caribbean (Ven).

Description: Medium sized fish that reached $12 \mathrm{~cm}$ of SL of silver and orange coloration on the base of the anal, dorsal and adipose fin. Lower jaw prominent.

Distribution: 296-248 m.a.s.l.; It wa s c ollected from the sector called the first bridge to the confluence with the Ortegüaza river (method of capture: traditional fishing). It was reported for the Amazon and Orinoco river basins (MOJ ICA et al., 2005; GREG ORY-MALDONADO 2006; MALDONADO-OCAMPO et al., 2008).

17. Serrasalmusrhombeus (LINEUS, 1766). Collection number ICN-MHN: 17911.

Subfamily: Serra sa Imina e.

Synonymies: Pygocentrusno ma ni, Serra sa Imo humera lisgra cilior, S. imma cula tus, S. normani, S. paraense.

Common name: Piranha, fist, Caribbea $n$ (Orinoco), black piranha (Bra).

Description: Medium fish that reached $13 \mathrm{~cm}$ of SL of orange coloration with met al.lic gray a reas, caudal fin with black border. Border of the elongated lower jaw with well-developed teeth (CASTRO, 1997).

Distribution: 296-248 m.a.s.l.; It was collec ted in the area called the first bridge to the confluence with the Ortegüaza river (method of capture: traditional fishing). Also, it is located in the basin of the Amazon River, Putumayo, Caquetá and Guavia re (GÉRY, 1977; MOJ ICA, et al., 2005; GREG ORY-MALDO NADO , 2006; MALDONADO-OCAMPO et al., 2008; WWW.SINCHI.org.co/2011).

18. Tetragonoptenus argenteus (C UVIER, 1816).

Collection number ICN-MHN: 17912.

Subfamily: Tetragonopterinae.

Common name: Palometa (Caquetá), Golden (Leticia), sabaleta, matupiri (Bra). 
Description: Medium fish that reached $13 \mathrm{~cm}$ of SL of silver colora tion and on the ventral edge of yellow color. It has a high, discoidal, deep and compressed body that differentia tes it from the Moenkha usia genus (GÉRY, 1977).

Distribution: 262-248 m.a.s.l.; It wa s loc ated in the urban area of the municipality of Florencia to the confluence with the O rtegüaza River (method of capture: Tra ditiona I fishing). Celis (2010) reported it for the Quebrada la Venado tributary of the Bodoquero River (Morelia-Caquetá). In the same way, it is located in the Amazon basin (MOJICA et al., 2005; MALDONADOOCAMPO et al., 2008; WWW.SINC HI.org. co/2011).

\section{Discussion}

Due to the few works developed on fish composition in the Colombian Amazonian Andean region, particularly in the Piedmont region of Caquetá, its wealth has been und erestima ted. In fact, the only investigations for the Hacha River Ba sin that address fish composition are that of Chaves (2011) for the order Siluriformes and Perdomo et al. (2012), this last a uthor reported 13 species for the order Characiformes, of which he didn't report for the Characidae family. Fowler $(1943,1945)$ reported 5 species for Caquetá, referenced in the present work. Likewise, 5 species of the Characidae family coincide with the reports made by Galvis et al. (2007) for the department (Annex C). Therefore, the 18 species collected in this basin can predict that the ric hness for the order Cha raciformes can reach 30 species, since they would increase by more than 10 species.

This research is a good a pproximation to the total number of species of the Characidae family present in the basin, considering the size of the basin, the explored places, the scarce records of species and the uncerta inties that a rise over existing id entific a tions (C HERNO FF et a l., 1999). In relation to the abundance and composition of the Characidae fa mily (459 ind (18sp) it is the one with the greatest contribution to the Characiformes order, since from the global study it showed only 70 individuals belonging to 11 species (families: Anostomidae, Crenuchidae, Curima ta dae, Erytrinidae, Hemiod ontidae, Pa rodontidae, Proc hilod ontidae) coinc id ing with other a uthors in several systems of the Amazon basin (SILVANO et al., 2000, LASSO et al., 2004).

Fishing in the munic ipality of Florencia is directly related to economic (income) and social a ctivities (population growth vs. food) (POMCA, 2005). However, according to the observation in the field and conversation with members of the community, it was identified that most of the species a re used in subsistence fishing; young fish are usually caught, which leads to the interruption of the reproductive cycle of the species and the consequent decrease in their populations. Among the ma in methods used for fishing a re hooks, trammel nets, fishing guns and cast nets.

Also, other factors that threaten the ic hthyofauna a re a gric ultural, domestic and ind ustrial pollution; these actions, added 
to the limited distribution ranges, place the fish at extinction risk levels. Therefore, of the 18 species referenced the only one that is in danger (vulnerable national category: A2c, d) according to Trehe Red Book of Freshwater Fishes of Colombia is Sa Iminus cf. a ffinis (MOJ ICA et al., 2012). Consequently, even though Sa Iminus cf. Affinis is in vulnerable danger, at the local level it is unknown that other species of fish may be in the same situation due to lack of studies.

Finally, it is urgent that research programs on the biology of species and the state of aquatic ecosystems be encouraged. Also, it is feasible to propose as conservation measures for the Hacha river basin the compliance with the regulation on the minimum sizes of capture and in general of the fishing and commercialization activity, through total or partial c losures during the reproduction periods.

As a conclusion, it can be indic a ted that the ric hness of species is high, partic ula rly in the lower basin of the HachaRiver. The most abundant and most widely distributed spec ies was Hemibryc on sp. (151), Boehlkea

\section{References}

ALBERT, J.S., BART, H.J. and REIS, R.E., 2011. Species richness and cladal diversity. Historical Biogeography of Neotropical Freshwater Fishes. University of California Press, Berkeley. pp. 89-104.

CASTRO, D., 1997. Peces del Rio Putumayo, Sector de Puerto Leguizamo. Corporación para el Desarrollo Sostenible del Sur de la Amazonia "CORPOAMAZONIA". $174 p$. cf. fred coc hui (88), Crea grutusa moenus (50) and Creagrutusc ochui (35). Also, of the 18 species collected, all are new reports for the basin, 12 in the department and one (1) in the Colombian Amazon.

\section{Acknowledgements}

The a uthorsthank the Universities of the Amazonia, Nacional and Nava ra (Spa in) for the loan of equipment and collections. Also to the CODECYT + I agreement $\mathrm{N}^{\circ}$ 098 of 2010 between Colciencias and Gobemación de Caquetá for the financial support through the young investigator scholarship. Also, we thank the different tea chers (Rafael Miranda, Dona ITha phorn, Germá nGa Ivis, J o sé Iván Mojica, Monica Shirley C elis, J a ime Velásquez, Alexa nder Velá squez and J ona tha $n$ Garaviz) for the comments and suggestions to this document and finally thank FAPESP (Fundacao de Amparo a la Pesquisa do Estado de Sa o Paulo - Brazil) and Professors J osé Galicia Tundisi and Takako Matsumura-Tundisi for the opportunity offered to carry out the Integrated Water Resources Management course and to socialize the research.

CELIS, M.S. and ORTIZ, J.L., 2003. Contenido Estomacal del Denton (Hopliasmalabaricus, bloch 1794) en una Madre Vieja del Piedemonte Amazónico. Universidad de la Amazonia. Trabajo de grado. 70p.

CELIS, M.S., 2010. Estructura de la comunidad íctica en un arroyo del Piedemonte Amazónico (Florencia Caquetá). Universidad Nacional de Colombia sede Leticia. Tesis de Maestría. Leticia - Amazonas. 44p. 
CHAVES, L.C., 2011. Distribución altitudinal de la familia Loricariidae en la región Andino-Amazónica Colombiana (cuenca del río Hacha, FlorenciaCaquetá). Universidad Nacional de Colombia; sede Leticia. Tesis de Maestría. 84p.

CHERNOFF, B., WILLINK, P., SARMIENTO, J., BARRERA, S., MACHADO-ALLISON, S., MENEZES, N. and ORTEGA, H., 1999. Fishes of the Rios Tahuamanu, Manuripi and Nareuda, Depto. Pando, Bolivia: Diversity, Distribution, Critical Habitats and Economic Value. pp. 39-46.

DIAZ, A.C. and ESCOBAR, F.R., 2004. Composición y abundancia Ictica de la Madre Vieja del rio Hacha en la Granja Villa Paola (Florencia, Caquetá) durante los meses de enero a junio de 2004. Universidad de la Amazonia. Tesis de grado. 65p.

ELOSEGI, A. and SABATER, S., 2009. Conceptos y Técnicas en Ecología Fluvial. BBVA. España. 424p.

FOWLER, H.W., 1943. Colección de peces de agua dulce de Colombia, Obtenida Principalmente por Hermano Nicéforo, María. Proceedings of the Academy of Natural Sciences of Philadelphia, vol. 95, pp. 223-266.

FOWLER, H.W., 1945. El estudio zoológico Colombiano Parte I: Peces de agua dulce. Proceedings of the Academy of Natural Sciences of Philadelphia, vol. 97, pp. 93-135.

GALVIS, G., MOJICA, J.I., BELTRAN, L.M., CIPAMOCHA, C.A. and LEIVA, M., 2007. Peces de la Amazonia Colombiana con Énfasis en Especies de Interés Ornamental. Ministerio de Agricultura y Desarrollo Rural. INCODER. Universidad Nacional de Colombia. Bogotá D.C. 489p.

GÉRY, J., 1977. Characids of the World. Printed in the U.S.A. 647p.

GÉRY, J., 1984. The fishes of Amazonia en: H. Sioli (Ed.), The Amazon: Limnology landscape ecology of a mighty tropical river and its basin. Monographiae Biologicae. vol. 56. Dr Junk Public. Dordrecht. pp. 353-370.

GREGORY, J.D and MALDONADO-OCAMPO, J., 2006. Peces de la Zona Hidrogeografica de la Amazonia, Colombia. Instituto de Investigaciones en Recursos Biológicos Alexander von Humboldt. Biota Colombiana, vol. 7, no. 1, pp. 55-94.
LASSO, C.A., MOJICA, J.I, USMA, J.S, MALDONADOOCAMPO, J.A., DONASCIMENTO, C. TAPHORN, D.C., PROVENZANO, F., LASSO-ALCALÁ, O.M., GALVIS, G. VÁSQUEZ, L., LUGO, M., MACHADO-ALLISON, A., ROYERO, R., SUÁREZ, C., ORTEGA-LARA, A., 2004. Peces de la cuenca del río Orinoco. Parte I: lista de especies y distribución por subcuencas. Biota Colombiana, vol. 5, no. 2, pp. 95-158.

LOBÓN-CERVIÁ, J., 1991. Dinámica de poblaciones de peces en ríos. Pesca eléctrica y métodos de capturas sucesivas en la estima de abundancias. Museo Nacional de Ciencias Naturales C.S.I.C., Madrid. 156p.

MALABARMA, L.R., 2003. Subfamily Cheirodontinae (Characins, tetras). pp. 215-221. En: Reis R.E., KULLANDER, S.O. y FERRARIS Jr., C.J. (eds.). 2003. Checklist of the Freshwater Fishes of South and Central America. Edipucrs. Porto Alegre, Brasil. 729p.

MALDONADO-OCAMPO, J.; ORTEGA, A., GALVIS, G., VILLA, F., VÁSQUEZ, L., PRADA, S., ARDILA, C., 2006. Peces de los Andes de Colombia. Guía de Campo. Instituto de investigaciones de Recursos Biológicos "Alexander Von Humboldt". Bogotá D.C-Colombia. $346 p$.

MALDONADO-OCAMPO, J., VARI, R.V., USMA, J.S., 2008. Checklist of the Freshwater Fishes of Colombia. Biota Colombiana, vol. 9, no. 2, pp. 143-237.

MOJICA-C, J.I., 1999. Lista Preliminar de las especies de peces dulceacuícolas de Colombia. Revista de la Academia Colombiana de Ciencias Exactas, Físicas y Naturales. vol 23, no. supl. esp. pp. 546-566.

MOJICA J.I, GÁLVIS, G., ARBELÁEZ, F., SANTOS, M., VEJARANO, S., PRIETO-PIRAQUIVE, E., ARCE, M., SÁNCHEZ-DUARTE, P., CASTELLANOS, C., GUTIÉRREZ, A., DUQUE, S. LEVON-GARCÍA, J. and GRANADOLORENCIO, C., 2005. Peces de la cuenca del río Amazonas en Colombia: Región de Leticia. Biota Colombia, vol. 6, no. 2, pp. 191-210.

MOJICA, J.I., USMA, J.S., ÁLVAREZ-LEÓN, R., and LASSO, C.A., 2012. Libro rojo de peces dulceacuícolas de Colombia 2012. Instituto de Investigación de Recursos Biológicos Alexander von Humboldt, Instituto de Ciencias Naturales de la Universidad Nacional de Colombia, WWF Colombia y Universidad de Manizales. Bogotá, D. C., Colombia, 319p. 
MOYLE P.B. and CECH, J.J., 2004. An introduction to ichthyology. Prentice Hall, Upper Saddle River, New York, USA. 726p.

NELSON, J.S., 2006. Fisches of the World. New York, John Wiley y Sons. 624p.

ORTEGA-LARA, A., AGUIÑO, A. and SÁNCHEZ, G.C., 2002. Caracterización de la ictiofauna nativa de los principales ríos de la cuenca alta del río Cauca en el departamento del Cauca. Informe presentado a la Corporación Autónoma Regional del Cauca, CRC. Fundación para la Investigación y el Desarrollo Sostenible, Funindes. Popayán, Colombia. 139p.

ORTEGA-LARA, A., MOJICA, J.I., ALONSO, J.C. and HIDALGO, M., 2006. Listado de Peces de la cuenca del Rio Putumayo en un sector Colombo-Peruano. Universidad Nacional de San Marcos, Lima. Universidad Nacional de Colombia. Instituto SINCHI. Biota Colombiana, vol. 7, no. 1, pp. 95-112.

PELÁEZ, R.M., GARCÍA, H. and MENDEZ, G.C., 2006. Caracterización y cuantificación de la carga contamínate transportada por el río Hacha (Florencia Caquetá). In: Neolimnos. VII Seminario Colombiano de Limnologia. Ibagué. pp. 17-28.

PERDOMO, A., VELÁSQUEZ, V.A. and CELIS, G.M., 2012. Análisis de la Composición espacial de la Comunidad de peces de la Cuenca Media del Río Hacha. Universidad de la Amazonia. Rev. Momentos de ciencia, vol. 9, no. 2, pp. 120-126.

POMCA, 2005. Plan de ordenación y manejo de la cuenca del río Hacha 2005-2025. Convenio 051 de 2004. 25p.
REIS, R., JAMES and KULLANDER, J. C., 2003. Check list of the freshwater fishes of south and Central America. Pontifícia Universidade Católica do Rio Grande do Sul. Porto Alegre. 729p.

ROMÁN-VALENCIA, C; RUIZ-C., R. I; TAPHORN, B. D. C. and GARCÍA-A., C., 2013. Three new species of Bryconamericus (Characiformes, Characidae), with keys for species from Ecuador and a discussion on the validity of the genus Knodus. Animal Biodiversity and Conservation, vol. 36, no. 1, pp. 123-139p.

RUBIO, E., 2007. Introducción a los Peces Dulceacuícolas de Colombia. Universidad del Valle. Impreso Cali Colombia. 404p.

RUEDA, D. M. and ALMARIO, A.R., 2004. Biosistemática de peces Eléctricos (Ostariophysi: Ginnitiformes) en Ecosistemas Acuáticos del Piedemonte Amazónico. Universidad de la Amazonia. Trabajo de grado. 55p.

SILVANO, R.A.M., DO AMARAL, B.D. and OYAKAWA, O.T., 2000. Spatial and temporal patterns of diversity and distribution of the upper Juruá River fish community (Brazilian Amazon). Environmental Biology of Fishes, vol. 57, no. 1, pp. 25-35.

VARGAS-TISNES, I.C., 1989. Inventario preliminar de la ictiofauna de la hoya hidrográfica del Quindío. Corporación Autónoma Regional del Quindío. Editorial Icnografía. Armenia, Colombia. 96 p. Available in: www.sinchi.org.co/coleccionesbiologicas/index.php 
ANNEXES

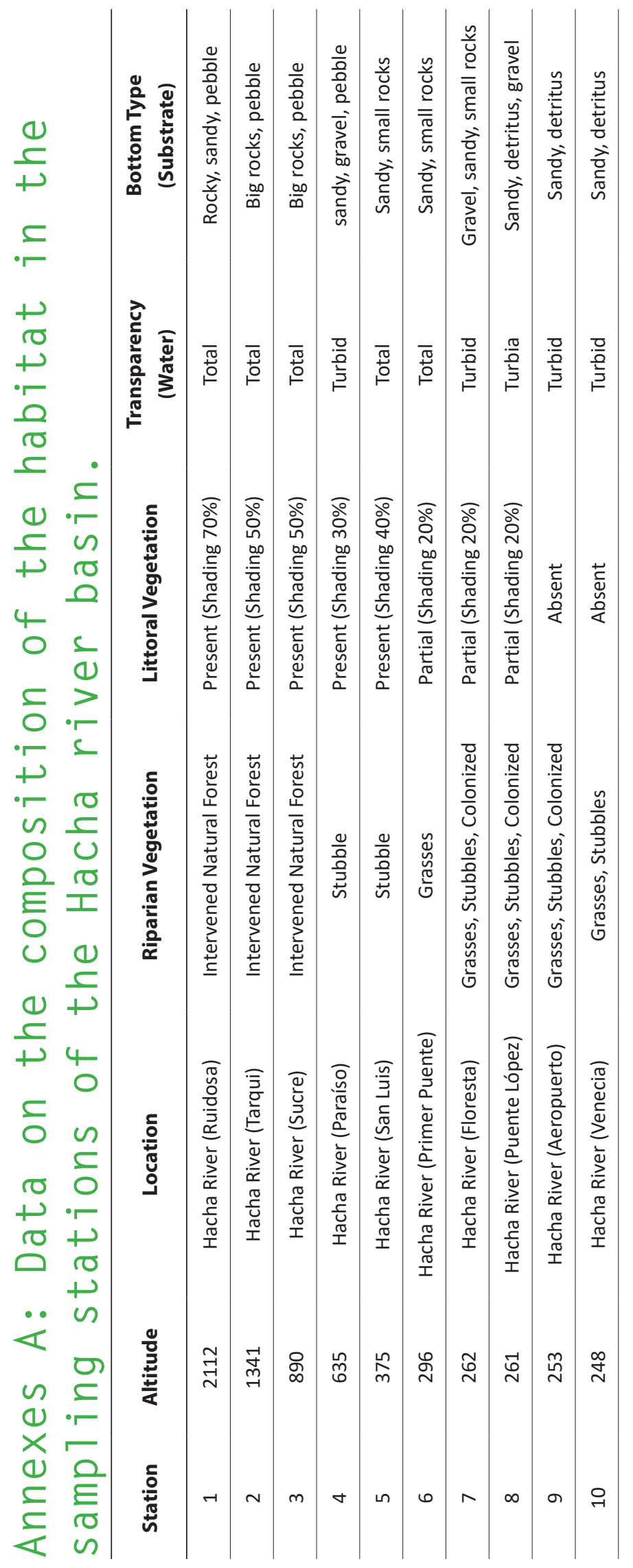




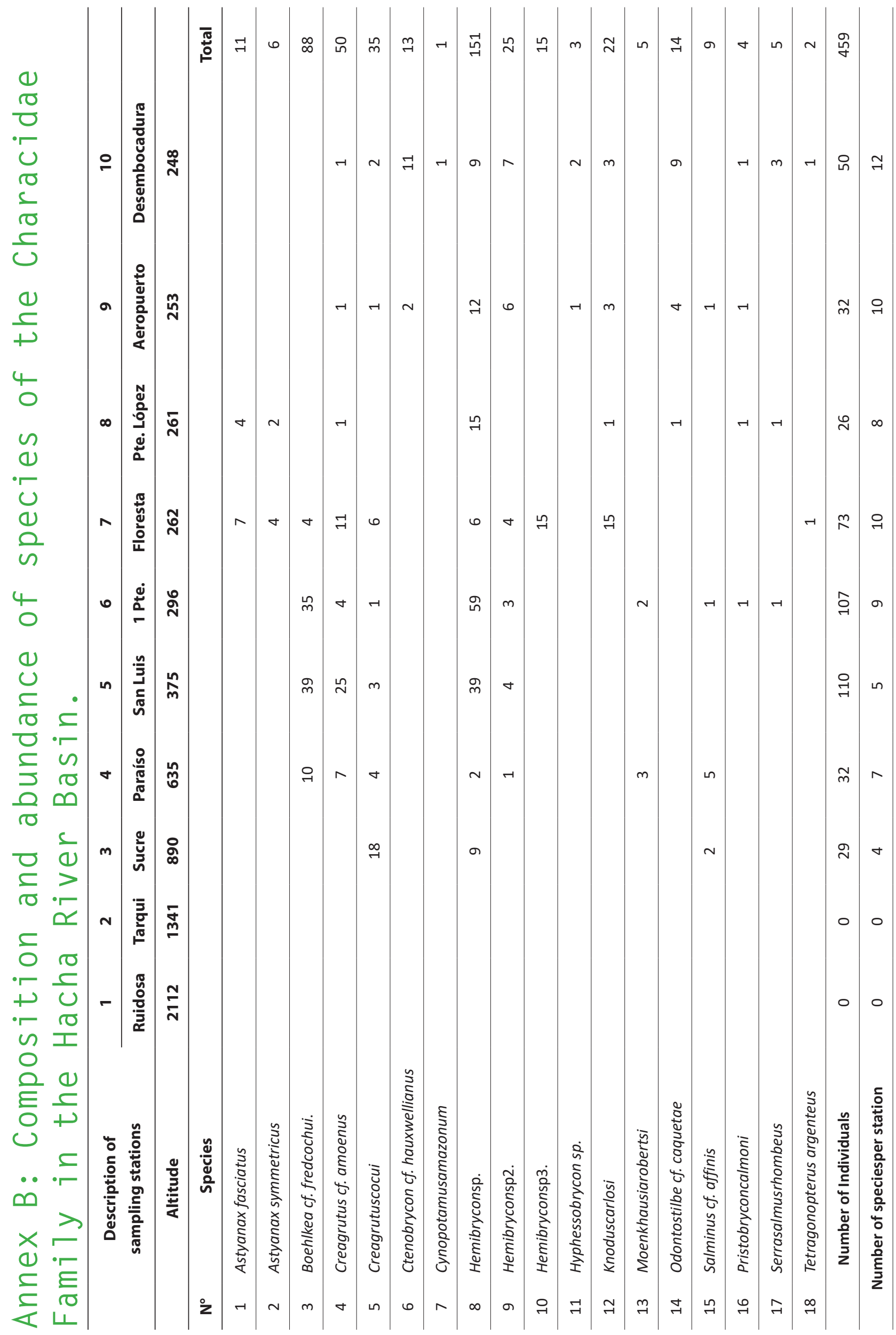




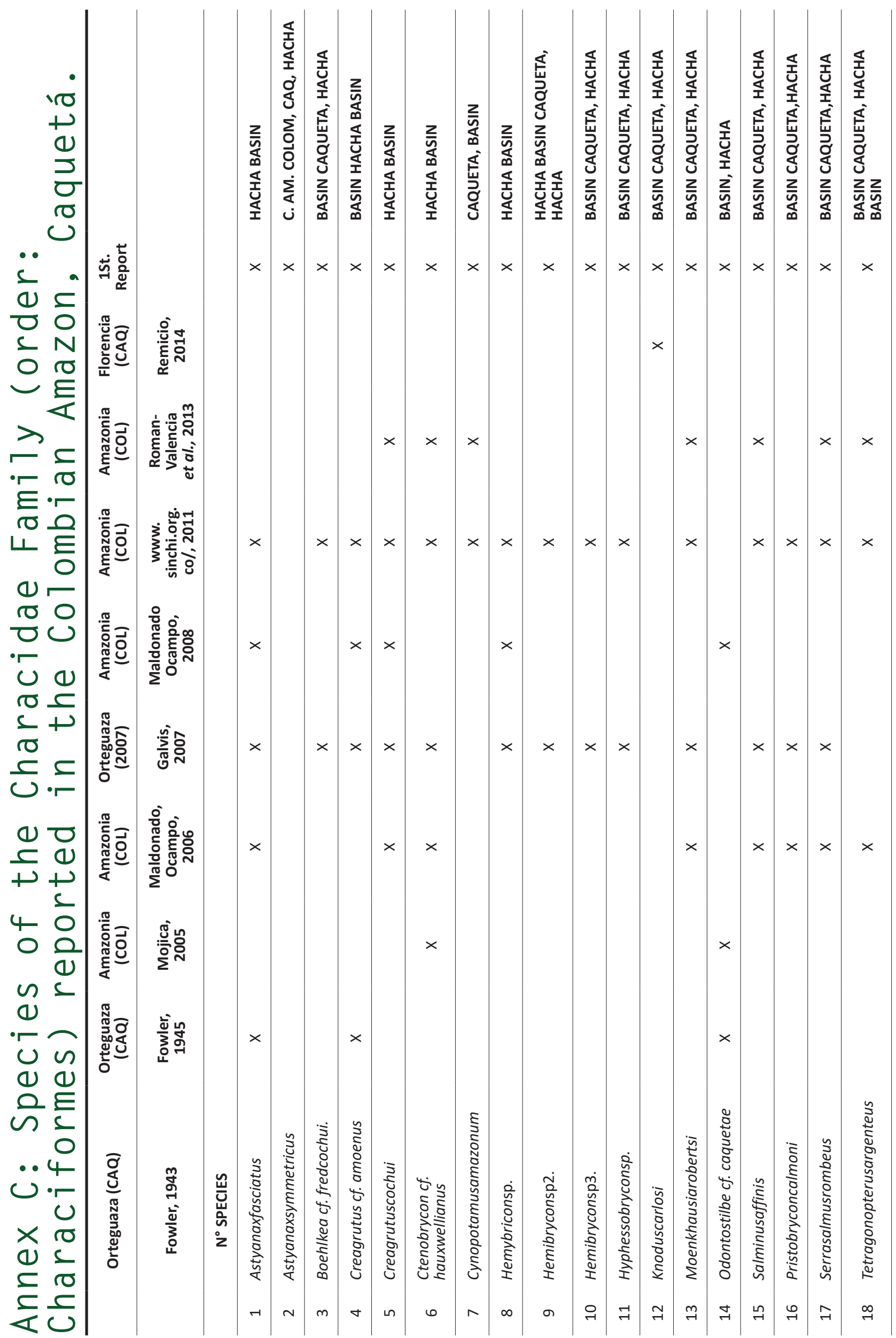

